\title{
Being smart: Emerging technologies and innovation in the public sector
}

\author{
J. Ramon Gil-Garcia ${ }^{\mathrm{a}, \mathrm{b}, *}$, Natalie Helbig ${ }^{\mathrm{b}}$, Adegboyega $\mathrm{Ojo}^{\mathrm{c}}$ \\ a Centro de Investigación y Docencia Económicas, Mexico \\ b Center for Technology in Government, University at Albany, USA \\ c Digital Enterprise Research Institute (DERI), Ireland
}

\section{A R T I C L E I N F O}

\section{Keywords:}

Smart government

Smart cities

Smart governance

Governance infrastructure

Emergent technologies

Innovation

\begin{abstract}
A B S T R A C T
Smart government is used to characterize activities that creatively invest in emergent technologies coupled with innovative strategies to achieve more agile and resilient government structures and governance infrastructures. However, there is no consensus in terms of what this term includes and how it is related to emergent technologies and innovation in the public sector. This introductory paper provides readers with ways to think about smart government and summarizes findings from twelve articles included in this special issue. These articles, which are the best papers of the 6th International Conference on the Theory and Practice of Electronic Governance (ICEGOV2012), contribute to emerging understanding of being smart in government settings. The articles span a great diversity of related topics such as smart cities, open government, and participation mechanisms. Collectively, the articles provide perspectives on the nature of smart governments and illustrate exemplar practices and initiatives on how governments are opening up and transforming service delivery to become smarter. The special issue in its entirety contributes to understanding governance structures, technical infrastructures, and other requirements geared toward supporting the operations of smarter governments around the world.
\end{abstract}

(c) 2014 Elsevier Inc. All rights reserved.

\section{Introduction}

A smart thermostat learns personal energy usage habits and automatically adjusts home heating and cooling systems to save money over time (Crist \& Wollerton, 2013), a smart umbrella is equipped with a sensor that detects raindrops falling and then sends the data via a cell phone to a computer network (Amos, 2014), and a smart watch monitors steps, heart rates, and caloric intake, providing personalized fitness and health profiles while enabling people to connect through social media and networks to make better choices and stay motivated (Fromm, 2014). These are just a few examples that represent the ways emerging technologies, nanotechnologies, and innovations are changing how we live, work, and spend our leisure time. They also influence, to a certain degree, citizens' expectations about how government should improve health care, deal with climate change, provide unemployment benefits, manage public works, or educate our children. Marketers and product developers are betting that individuals want individualized attention and also want access to people like them to share information with while they are on the go. While this may be an

\footnotetext{
* Corresponding author.

E-mail addresses: jgil-garcia@ctg.albany.edu, joseramon.gil@cide.edu (Gil-Garcia, J. Ramon).
}

idealized version of what the future might look like, versions of this kind of reality already exist, even within government.

Smart, in purely definitional terms, has many synonyms, including percipient, astute, shrewd, and quick. A smart government, or the organizations and networks within a political jurisdiction (e.g., a city, a town, a nation), would use emerging and nanotechnologies and various innovation strategies to gain a good understanding of their communities and constituencies (being percipient), they would use that ability to accurately assess situations or people (being astute), show sharp powers of judgment (being shrewd), and then make decisions and respond quickly or effectively (being quick). Current examples of smart cities often highlight Santander, Spain, a test-bed site for the most 'sensor-equipped' city in the world. Funded by a multi-million dollar grant from the European Union, the city installed more than 20,000 fixed and mobile sensors to be able to examine parking trends, manage energy supply to schools, buildings and street lights, better understand waste collection and water management and provide more personalized citizen services in areas such as public transit or shopping (Newcombe, 2014). Meanwhile, less aggressive strategies are occurring all around the world including in Las Vegas, Nevada, where intelligent street lights create the capability for the government to monitor air pollution levels and foot traffic (Newcombe, 2014).

Being a smarter government seems to require having a forwardthinking approach to the use and integration of information, technology, and innovation in the activities of governing. While the concept smart government has yet to be rigorously developed in extant literature, and 
there is little consensus regarding its definition, a few studies have described some elements and characteristics. Coe, Paquet, and Roy (2001) document early examples of smartness from Canada's 'smart communities' initiative, where they draw from Eger's (1997) definition of 'smart communities' as - "a geographical area ranging in size from a neighborhood to a multicounty region within which citizens, organizations, and governing institutions deploy NICTs [new information communication technologies] to transform their region in significant and fundamental ways" (Coe et al., 2001, p. 85). Kliksberg's (2000) conceptualization focuses on government's strategic role in society and the development of managerial capacities that enable it to perform its roles in a highly effective manner. Smart government in the social sphere is not a detached government that carries out short-term welfare-based actions, but rather one with a state policy (as opposed to a party policy) on education, health, nutrition and culture which is oriented toward overcoming gross inequities and promoting cooperation between the economic and social fields, while enhancing the contribution of civil society through an ongoing synergetic role. Elements of smart government in this conception include coordination between economic and social policy, improvement in intra-governmental coordination in the social sphere, decentralization, increased participation, and renewal of organizational structures. Key and We (2009) move further down the spectrum by more narrowly viewing smarter government as enabling smart information technology government operations such as establishing a government-wide, fee-based IT expert center/clearing house, organizing cross-agency birds of a feather working groups for every IT field; providing an infrastructure for educational training and easy online access to technical papers; and instituting procurement strategies anchored on technical expertise and cross agency cooperation.

Scholl and Scholl (2014) discuss the evolution of the term 'smart government' as a companion concept to the relatively more developed term 'smart governance'. Drawing from Willke's (2007) definition of smart governance - "an abbreviation for the ensemble of principles, factors, and capacities that constitute a form of governance able to cope with the conditions and exigencies of the knowledge society" (p. 165), Scholl and Scholl (2014) outline a set of smart government elements: openness and decision making, open information sharing and use, stakeholder participation and collaboration, and improving government operations and services, all through the use of intelligent technologies as they act as a facilitator of innovation, sustainability, competitiveness, and livability (p. 166). To add to the distinction between smart government and smart governance, we turn to Bingham, Nabatchi, and O'Leary's (2005) distinction between the two: “Government occurs when those with legally and formally derived authority and policing power execute and implement activities" and "Governance refers to the creation, execution, and implementation of activities backed by the shared goals of citizens and organizations, who may or may not have formal authority or policing power" (Bingham et al., 2005, p. 548). Therefore, we might conclude that smart governments implement smarter governance initiatives. Similarly, Gil-Garcia (2012b) emphasizes greater interorganizational collaboration, information sharing and integration as a core aspect of a smart state or smart government dealing with complex social problems.

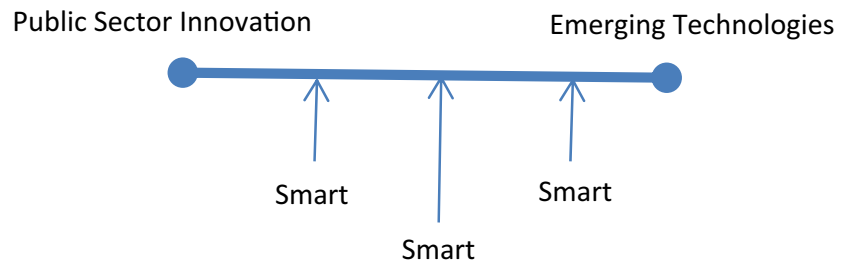

Fig. 1. Continuum of smart government strategies rooted in emerging technologies and public sector innovation.
Therefore, there are many different views and perspectives on smartness and smart governments. Some of them are very broad and include the very essence of governing and some of them are highly centered on the use of emergent information and technologies.

Smart is not an end state, but can be an enabling condition that may or may not lead to other desirable outcomes. This special issue explores the notion of being smart through research that examines how governments are implementing smart governance practices to cope with complex and uncertain environments while building requisite capacity to achieve resilience (Scholl \& Scholl, 2014). This paper is organized in four sections, including this introduction. Section 2 describes two important characteristics of being smart, emerging technologies and innovation in the public sector. Section 3 summarizes the papers and maps out their contributions and perspectives on 'being smart' activities, tools, and strategies. Finally, Section 4 provides some concluding remarks. This issue assembles research on the emerging area of smart government and governance and furthers the dialog that began at the 6th International Conference on Theory and Practice of Electronic Governance (ICEGOV2012). The papers provide perspectives on how governments are opening up their processes and data, transforming service delivery, transforming cities, as well as some powerful methodological and theoretical contributions.

\section{Smart governments: a creative mix of emerging technologies and innovation in the public sector}

We suggest one way to understand smart government is to see it as the deployment of a creative mix of emerging technologies and innovation in the public sector, which is based on specific contexts and problems (Fig. 1). New and emergent technologies, over the last three decades, have continuously disrupted the administrative landscape of bureaucracies and the public sector around the world. Governments at different levels, and across different branches, are adopting tools and applications to reach out, to deliver, to function, and to organize themselves in ways that allow them to cope with rapid changes. The path toward being smart is not without challenges (Gil-Garcia \& Pardo, 2005; Loukis \& Charalabidis, 2011). While innovation and emergent technologies offer myriad possibilities, such disruptive forces often test the basic characteristics of public programs and identify gaps in capabilities (Dawes \& Nelson, 1995). Some governments are focusing on public sector innovation that has very little to do with emergent technologies and others are focusing more on emergent technologies. Different governments are likely to find themselves at various points along a continuum in terms of an overall 'smart government' strategy, and each smart initiative will also be at different points along the continuum. In the next sections we describe briefly the literature on emerging technologies and public sector innovation, which help to ground the two main components of smart government strategies.

\subsection{Emerging information technologies}

The history of the use of information technologies in government is well documented, starting in the early 1960s (Danziger \& Andersen, 2002; Fountain, 2001). During the 1990s, the internet changed the ways that government used technology internally, provided services, and reached out to citizens and users (Carter \& Belanger, 2005; Reddick \& Turner, 2012). Today's versions of electronic government include the promises and challenges associated with different levels of communication and interaction in a changing environment of tools and applications (Gil-García, 2012a). New information resources, technologies, and strategies available include big data, open government data, social networking, blogs, Really Simple Syndication (RSS) feeds, web design and programs (i.e., html5, xhtml, SQl, and more), mobile government, smartphone applications, cloud computing, sensors, and more (Ambite et al., 2002; Criado, Sandoval-Almazan, \& Gil-Garcia, 2013; Jaeger, Lin, \& Grimes, 2008; Mahler \& Regan, 2011). From mobile 


\section{دريافت فورى ـ ـ متن كامل مقاله}

\section{ISIArticles}

مرجع مقالات تخصصى ايران

ل امكان دانلود نسخه تمام متن مقالات انكليسى ل امكان دانلود نسخه ترجمه شده مقالات ل يذيرش سفارش ترجمه تخصصى $\checkmark$ ل امكان جستجو در آرشيو جامعى از صدها موضوع و هزاران مقاله ل امكان دانلود رايكان r صفحه اول هر مقاله

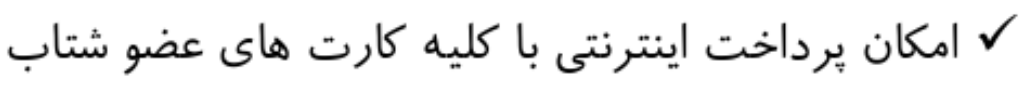
ل دانلود فورى مقاله پِ از برداخت آنلاين

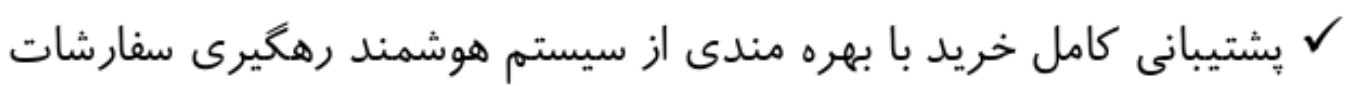

